\author{
Dian Kumala Muman' dan Mahendra Nur Hadiansyah ${ }^{2}$ \\ Program Studi Desain Interior \\ Universitas Telkom \\ 1 dian.kumala.m@gmail.com \\ ${ }^{2}$ mahendra.tcis@gmail.com
}

\title{
ANALISIS JARAK DAN SUDUT PANDANG POSISI DUDUK PADA RUANG PERKULIAHAN TERHADAP EFEKTIVITAS BELAJAR MAHASISWA DI GEDUNG TOKONG NANAS UNIVERSITAS TELKOM
}

\begin{abstract}
Abstrak: Desain ruang perkuliahan mempunyai peranan yang cukup penting dalam meningkatkan efektivitas mahasiswa saat belajar. Untuk meningkatkan efektivitas dalam belajar, diperlukan suatu ruang perkuliahan yang memiliki fasilitas belajar dengan peletakan yang sesuai dengan standar dan kebutuhannya. Fasilitas belajar dapat dikatakan sesuai dengan standar dan kebutuhannya apabila layout yang diterapkan mendukung aktivitas pengguna ruang secara efektif. Layout memiliki konfigurasi yang bermacam-macam. Dalam penelitian ini, dari beberapa konfigurasi layout yang ada pada lantai 6 di Gedung Tokong Nanas Universitas Telkom, akan diteliti aktivitas pengguna ruang untuk mengetahui layout yang seperti apa yang baik diterapkan dalam ruang perkuliahan. Yang mana hal tersebut dapat menunjang efektivitas mahasiswa dalam belajar. Permasalahan dalam penelitian ini adalah bagaimana pengaruh layout terhadap efektivitas belajar dalam ruang perkuliahan. Selain itu, bagaimana layout yang baik ditinjau dari perilaku pengguna ruang perkuliahan di Gedung Tokong Nanas. Tujuan penelitian ini dilakukan untuk mengetahui dan menganalisa seberapa besar pengaruh layout dalam ruang perkuliahan terhadap efektivitas mahasiswa dalam belajar. Selain itu, untuk melihat dan menganalisa kembali ketepatan kegunaan prinsip desain layout pada ruang perkuliahan. Metode penelitian dilakukan secara kualitatif dengan menggunakan metode analisa deskriptif, dan mengambil lokasi ruang kuliah di Gedung Tokong Nanas Universitas Telkom. Data yang ada dikumpulkan dengan metode pengamatan serta studi dokumentasi. Penelitian dilakukan bertujuan mengetahui bagaimana layout yang baik di dalam ruang perkuliahan sesuai dengan anthropometri dan standar ergonomi. Hipotesis yang diajukan adalah layout dalam desain ruang perkuliahan dapat menjadi salah satu faktor penting terhadap efektivitas belajar mahasiswa. Ruangan kelas yang kondusif dapat tercipta dengan adanya desain layout yang baik tanpa mengabaikan standar ergonomi dan kesesuaian dengan anthropometri.
\end{abstract}

Kata kunci: Efektivitas Belajar, Fasilitas Belajar, Layout

\begin{abstract}
One of the reasons students feel less comfortable when the learning process is learn support facilities that are not laid out to the maximum so inhibiting even more disruptive. 6th floor class room in Tokong Nanas Telkom University is taken as a case study in this research. To improve the effectiveness of learning, we need a class room which has a learning facility with laying accordance with the standards and needs. The learning facilities can be said to be in accordance with the standards and needs when layout and facilities were implemented to support the activities of the space effectively. In this discussion the main topic focused on the distance and viewing angle sitting position in which it can support the effectiveness of student learning. The hypothesis is the distance and viewing angle sitting position in a class room design can be one of the factors supporting the effectiveness of the learning process. The study was conducted by observing the activities of the students studying at Telkom University, which aims to determine how the layout is specifically the distance and viewing angle sitting position in a class room either of the application layout on the seat in class room as well as other factors that influence so as to create effectiveness during the process student learning. The purpose of this study was conducted to determine and analyze how much influence the distance and viewing angle sitting position in a class room on the effectiveness of student learning. Research conducted qualitatively using descriptive analysis and take a place in the class room building
\end{abstract}


Tokong Nanas Telkom University. The existing data collected by the method of measurement and documentation as well as studies. The results of the analysis can be broadly concluded that the distance and sitting positions (both horizontal and vertical) effect on the effectiveness of the student in the learning process. In the class room in Tokong Nanas building is generally already meet the standard distance and viewing angle sitting position. However, there are some aspects that do not meet the standards.

Keywords:, Amenities, Distance, Effectiveness, Viewpoint

\section{Pendahuluan}

Efektivitas sangat dibutuhkan dalam aktivitas belajar, yang mana hal tersebut dapat mempengaruhi hasil ilmu yang akan dicapai. Dalam mewujudkan efektivitas belajar tersebut, terdapat beberapa faktor yang mempengaruhinya, antara lain : karakteristik siswa, guru, dan kelompok, interaksi dari metode, fasilitas fisik, mata pelajaran, dan lingkungan luar. Fasilitas fisik yang mempengaruhi jalannya proses belajar mengajar dan hasil-hasil yang akan dicapai adalah kemudahan fisik yang ada di sekolah, seperti kondisi ruang belajar/kelas, bangku, papan tulis dan perangkat fisik lainnya yang berhubungan dengan kepentingan proses belajar mengajar (Muhibbin, 2006). Ruang belajar yang umumnya digunakan untuk aktivitas belajar adalah ruang perkuliahan. Desain ruang perkuliahan mempunyai peranan yang cukup penting dalam meningkatkan kefokusan mahasiswa saat belajar. Sering kali mahasiswa merasa kurang nyaman pada saat proses belajar. Salah satu penyebab terjadinya hal tersebut karena fasilitas pendukung belajar yang tidak ditata secara maksimal sehingga menghambat bahkan mengganggu proses belajar.

Fasilitas belajar adalah salah satu elemen yang cukup penting dalam menentukan efektivitas belajar dalam ruang perkuliahan. Ketepatan penataan fasilitas belajar merupakan salah satu aspek pendukung berhasilnya suatu proses belajar dalam ruang perkuliahan. Untuk meningkatkan efektivitas dalam belajar, diperlukan suatu ruang perkuliahan yang memiliki fasilitas belajar dengan peletakan yang sesuai dengan standar dan kebutuhannya. Fasilitas belajar dapat dikatakan sesuai dengan standar dan kebutuhannya apabila layout dan fasilitas yang diterapkan mendukung aktivitas pengguna ruang secara efektif.

Ruang perkuliahan lantai 6 di Gedung Tokong Nanas Universitas Telkom diambil sebagai studi kasus pada penelitian ini. Dalam penelitian ini, dari beberapa konfigurasi layout yang ada pada lantai 6 di Gedung Tokong Nanas Universitas Telkom, akan diteliti aktivitas pengguna ruang untuk mengetahui layout yang seperti apa yang baik dalam ruang perkuliahan. Pada bahasan ini topik utama terfokus pada jarak dan sudut pandang posisi duduk yang mana hal tersebut dapat menunjang efektivitas mahasiswa dalam belajar.

Dari penjelasan di atas, dapat ditarik beberapa rumusan masalah yang muncul yaitu bagaimana pengaruh jarak dan sudut pandang penglihatan dari posisi duduk terhadap efektivitas 
belajar dalam ruang perkuliahan. Selain itu, bagaimana posisi yang paling ideal ditinjau dari jarak dan sudut pandang penglihatan pengguna ruang perkuliahan di Gedung Tokong Nanas.

Hipotesis yang diajukan adalah jarak dan sudut pandang penglihatan pada posisi duduk dalam desain ruang perkuliahan dapat menjadi salah satu faktor pendukung efektivitas proses belajar. Ruang perkuliahan yang kondusif dapat tercipta dengan adanya layout yang baik.

Penelitian dilakukan dengan mengamati aktivitas proses mahasiswa belajar di Universitas Telkom yang bertujuan mengetahui bagaimana layout secara khusus jarak dan sudut pandang penglihatan dari posisi duduk di dalam ruang perkuliahan baik dari penerapan tata letak pada kursi kuliah maupun faktor-faktor lain yang mempengaruhinya sehingga dapat tercipta efektivitas pada saat proses belajar mahasiswa.

\section{Kajian Literatur}

\subsection{Efektivitas Belajar}

Berikut faktor yang dapat mempengaruhi belajar siswa (Muhibbin, 2006) :

1. Karakteristik siswa, guru, dan kelompok

Karakteristik siswa baik secara internal maupun eksternal secara jasmaniah maupun rohaniah paling berpengaruh terhadap proses belajar. Karakteristik guru merupakan faktor yang sangat berpengaruh terhadap keberhasilan seorang guru sebagai pembimbing sumber daya manusia. Oleh karena itu, setiap calon guru dan guru professional sangat diharapkan memahami bagaimana karakteristik kepribadian dirinya yang diperlukan sebagai panutan para siswanya. Kesatuan yang terdiri atas siswa dalam sebuah kelas disebut kelompok. Kesatuan siswa ini memiliki karakteristik tertentu dan turut pula mempengaruhi hasil pembelajaran setiap siswa dalam kelas itu. Karakteristik kesatuan siswa yang dapat mempengaruhi jalannya proses belajar mengajar dan hasil pembelajaran siswa itu.

2. Interaksi dari metode

Dalam setiap proses belajar mengajar sekurang-kurangnya melibatkan 4 komponen pokok yaitu individu siswa, guru, ruang kelas dan kelompok siswa. Melalui interaksi antara guru dengan siswa dan interaksi antara sesama siswa (komunikasi dua arah dan multiarah) dalam proses belajar mengajar akan menimbulkan perubahan perilaku siswa baik yang berdimensi ranah cipta, ranah rasa, maupun yang berdimensi ranah karsa.

3. Fasilitas fisik

Fasilitas (kemudahan) fisik yang mempengaruhi jalannya proses belajar mengajar dan hasil-hasil yang akan dicapai adalah, kemudahan fisik yang ada di sekolah, seperti kondisi ruang belajar/kelas, bangku, papan tulis, laboratorium, perpustakaan dan perangkat fisik lainnya yang berhubungan dengan kepentingan proses belajar mengajar. 


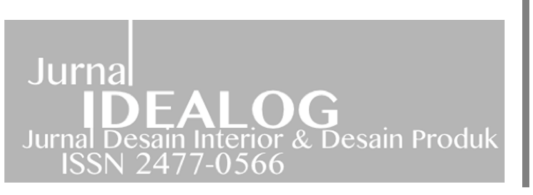

4. Mata pelajaran

Tingkat kesukaran, keluasan dan kedalaman makna yang terkandung dalam bahan pelajaran akan turut mempengaruhi sikap dan minat belajar para siswa selama mengikuti proses belajar mengajar. Oleh sebab itu, setiap bahan pelajaran ditata sedemikian rupa hingga memenuhi syarat psikologis-pedagogis.

5. Lingkungan luar

Faktor lingkungan luar (kondisi lingkungan) yang mendorong kelancaran atau kemacetan proses belajar mengajar meliputi, lingkungan sekitar seperti keadaan lingkungan gedung sekolah, kondisi masyarakat sekitar sekolah, situasi kultural sekitar sekolah, juga sistem pendidikan dan organisasi serta administrasi sekolah. Selain itu juga dapat dipengaruhi oleh lingkungan sekitar rumah siswa, seperti tetangga, fasilitas/sarana umum, strata sosial masyarakat, situasi kultural, dan sebagainya.

Terdapat beberapa faktor yang dapat mempengaruhi dalam proses belajar, salah satunya fasilitas fisik. Fasilitas fisik berperan penting terhadap jalannya proses belajar mengajar. Dalam studi kasus ini, pembahasan secara khusus dari faktor fasilitas fisik yang ditinjau dari kondisi ruang kelas antara lain: papan tulis, layar proyektor, meja dosen, dan kursi mahasiswa.

\subsection{Pengaturan Tempat Duduk}

A. Pola Pengaturan Tempat Duduk pada Ruang Kelas
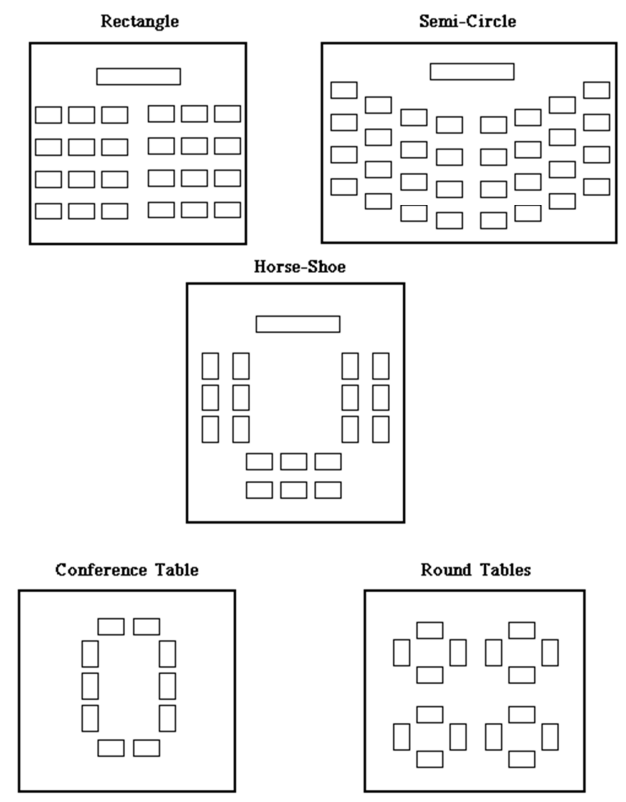

Gambar 1. Pola Pengaturan Tempat Duduk 
Pola rectangle adalah pola bersusun membentuk persegi dengan 1 titik acuan di depan. Pola seperti ini paling umum digunakan pada ruang belajar seperti ruang kelas TK, SD, SMP, SMA, maupun ruang perkuliahan. Pola ini untuk ruang dengan kelompok yang membutuhkan sedikit diskusi.

Pola semi-circle adalah pola bersusun membentuk lengkung dengan 1 titik acuan di depan. Pola seperti ini biasanya digunakan untuk ruang auditorium dan ruang bioskop. Pola ini untuk ruang dengan kelompok yang membutuhkan sedikit diskusi.

Pola horse-shoe adalah pola bersusun yang berkeliling dari beberapa pola yang sama dengan 1 titik acuan di depan. Pola seperti ini biasanya digunakan pada ruang workshop dan ruang perkuliahan.

Pola conference table adalah pola bersusun yang berkeliling dengan 1 titik acuan di tengah. Pola seperti ini biasanya digunakan pada ruang meeting atau ruang konfrensi. Pola ini untuk ruang dengan kelompok yang membutuhkan banyak diskusi.

Pola round tables adalah pola bersusun dari beberapa pola yang sama dengan beberapa titik acuan. Pola seperti ini biasanya digunakan pada ruang studio atau ruang untuk kegiatan internal.

Pada studi kasus, kondisi ruang kelas menerapkan pola rectangle. Ruang kelas ini memiliki tempat duduk tersusun membentuk pesegi dengan 1 titik acuan. Titik acuan pada ruang adalah layar proyektor dan papan tulis.

B. Pengaturan Tempat Duduk dengan Layar Proyektor (University of Maryland, 2000), (Ahlstrom, 2007) :

1. Pengukuran sudut horizontal menggunakan busur dilakukan dengan acuan titik tengah layar terhadap area terluar posisi duduk. Sedangkan standar yang dipakai untuk ukuran ini adalah $45^{\circ}+45^{\circ}$.

2. Standar untuk jarak kursi terdekat dekat dengan layar adalah $2 \mathrm{xH}$, dimana $\mathrm{H}$ adalah tinggi layar, sedangkan standar kursi terjauh dari layar adalah $6 \mathrm{xH}$.

3. Untuk perhitungan sudut vertikal (visual angle = VA), terlebih dahulu diukur jarak kursi relatif terhadap layar proyektor. Sebagai standar digunakan VA sebesar $30^{\circ}$. 


\section{Metoda Penelitian}

Penelitian dilakukan secara kualitatif menggunakan metode analisa deskriptif dan mengambil lokasi ruang kuliah di Gedung Tokong Nanas Universitas Telkom. Data yang ada dikumpulkan dengan metode pengukuran dan serta studi dokumentasi. Saat penelitian dilakukan pengukuran terhadap berbagai data primer diantaranya jenis dan ukuran fasilitas duduk ruang perkuliahan, tata letak furnitur, data anthropometri pengguna ruang, dan aktivitas pengguna ruang.

Pengamatan dilakukan dengan melakukan dokumentasi aktivitas pengguna dalam ruang kuliah yang dilakukan. Dokumentasi dilakukan secara terbuka sebagai penunjang akurasi data, dan bertujuan menyaring informasi yang lebih mendetil dan relevan. Dokumentasi terhadap pengguna ruang difokuskan pada kebiasaan mahasiswa pada saat kuliah dan terfokus pada posisi duduk.

Setelah data didapat, dilakukan analisis layout ditinjau dari faktor-faktor penunjang efektivitas mahasiswa dalam belajar yang dilihat dari aktivitas di dalam ruang perkuliahan serta perbandingan antara layout 1 dengan yang lain. Kemudian dilakukan perbandingan dengan standar sesuai yang ada di literatur.

Penelitian membahas konfigurasi tempat duduk hanya 4 tipe karena memiliki lokasi yang sama, jarak yang sama, dan ukuran ruang kelas yang sama. Untuk itu sample yang digunakan hanya 1, yang mewakili semua kelas di lantai 6.

\section{Hasil Pembahasan}

\subsection{Layout Ruang Perkuliahan Keseluruhan pada Lantai 6}

Pada ruang perkuliahan di lantai 6 terdapat ruang perkuliahan dan ruang auditorium. Dalam analisa ini hanya di ambil 1 lantai sebagai sample karena memiliki layout yang sama di masing-masing lantai. Berikut denah ruang perkuliahan lantai 6 : 

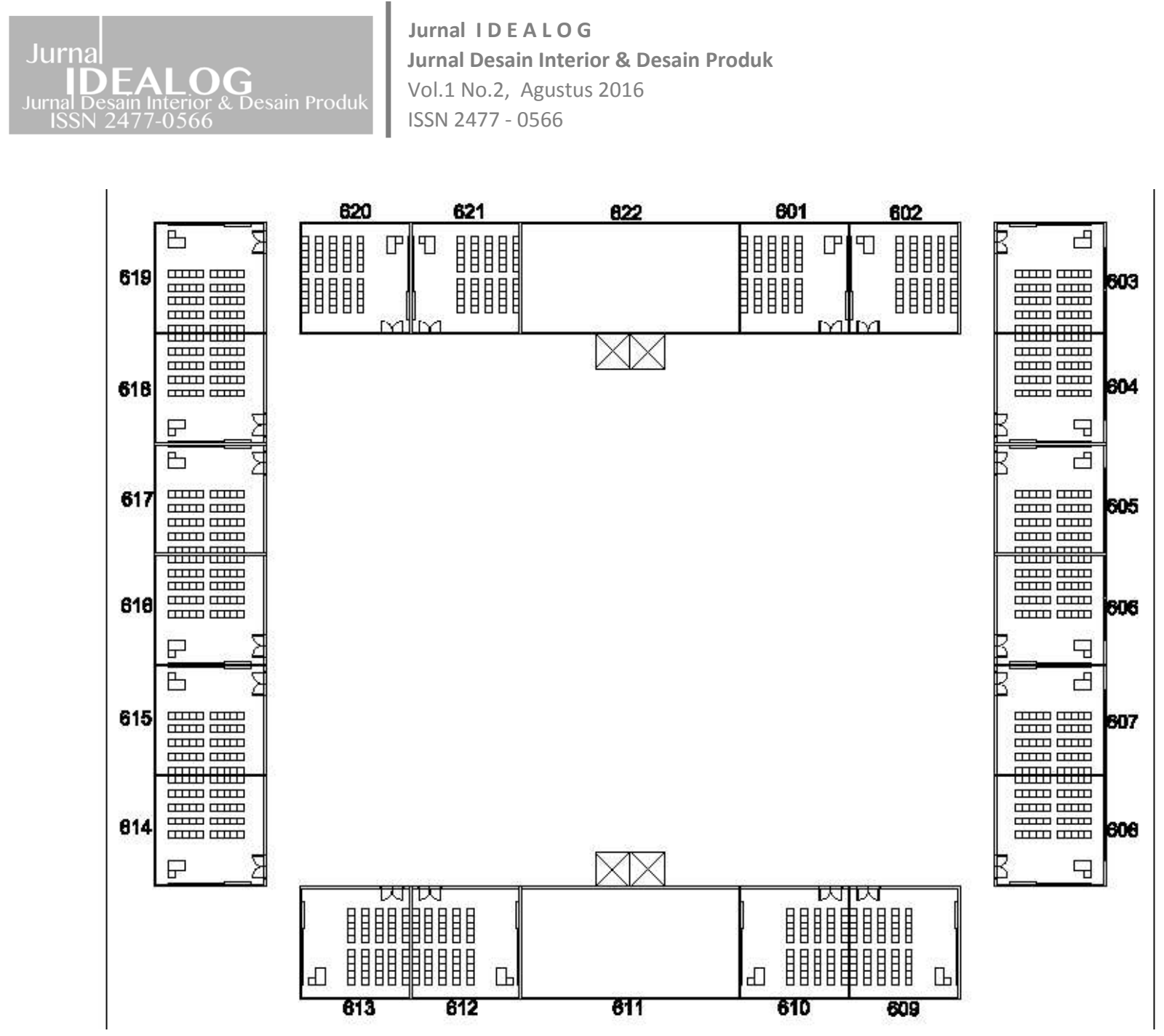

Sumber: pribadi

Gambar 2. Denah Layout Lantai 6

Di lantai 6 ini terdapat 20 ruang perkuliahan dan 2 ruang auditorium. Letak ruang auditorium tepat berhadapan dengan lift, yaitu ruang 611 dan 622. Ruang selain 611 dan 622 adalah ruang perkuliahan.

\subsection{Konfigurasi Layout Ruang Perkuliahan}

Setelah diketahui penyusunan denah layout pada lantai 6, didapat 4 tipe konfigurasi layout ruang kelas. Berikut tipe konfigurasi layout ruang perkuliahan lantai 6 : 


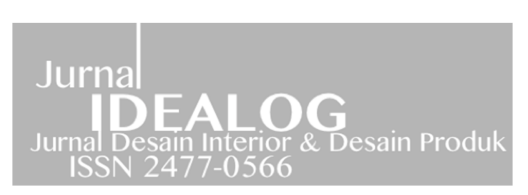

Jurnal I D E A L O G

Jurnal Desain Interior \& Desain Produk

Vol.1 No.2, Agustus 2016

ISSN 2477 - 0566

Tabel 1. Tipe Konfigurasi Layout

\begin{tabular}{|c|c|c|c|c|}
\hline NO & TIPOLOGI & GAMBAR & RUANG & DESKRIPSI \\
\hline 1. & TIPE 1 & 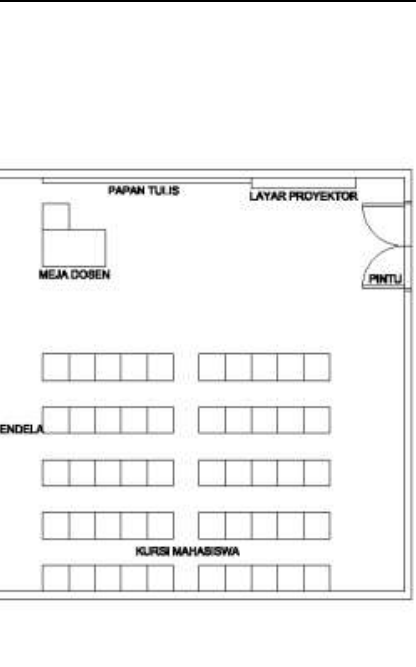 & $\begin{array}{l}601,604, \\
606,608, \\
615,617, \\
619,620 .\end{array}$ & $\begin{array}{c}\text { Pada tipe ini, } \\
\text { letak pintu } \\
\text { masuk } \\
\text { berhadapan } \\
\text { langsung } \\
\text { dengan meja } \\
\text { dosen. } \\
\text { Untuk } \\
\text { masuk ke } \\
\text { ruang kelas } \\
\text { harus } \\
\text { melewati } \\
\text { layar } \\
\text { proyektor. }\end{array}$ \\
\hline 2. & TIPE 2 & 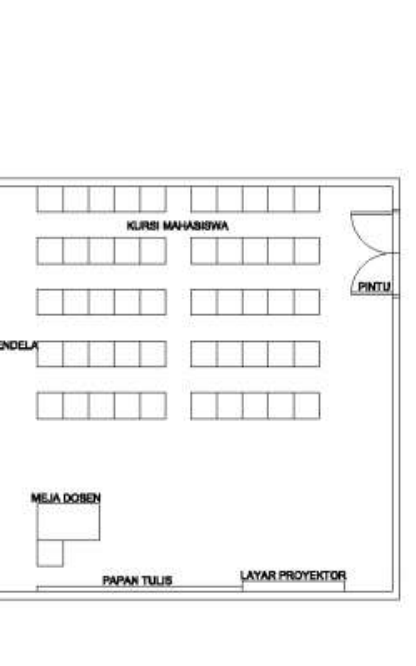 & 609,612 . & $\begin{array}{c}\text { Pada tipe ini, } \\
\text { letak pintu } \\
\text { masuk } \\
\text { berhadapan } \\
\text { langsung } \\
\text { dengan kursi } \\
\text { mahasiswa. } \\
\text { Untuk } \\
\text { masuk ke } \\
\text { ruang kelas } \\
\text { tidak harus } \\
\text { melewati } \\
\text { layar } \\
\text { proyektor. }\end{array}$ \\
\hline
\end{tabular}



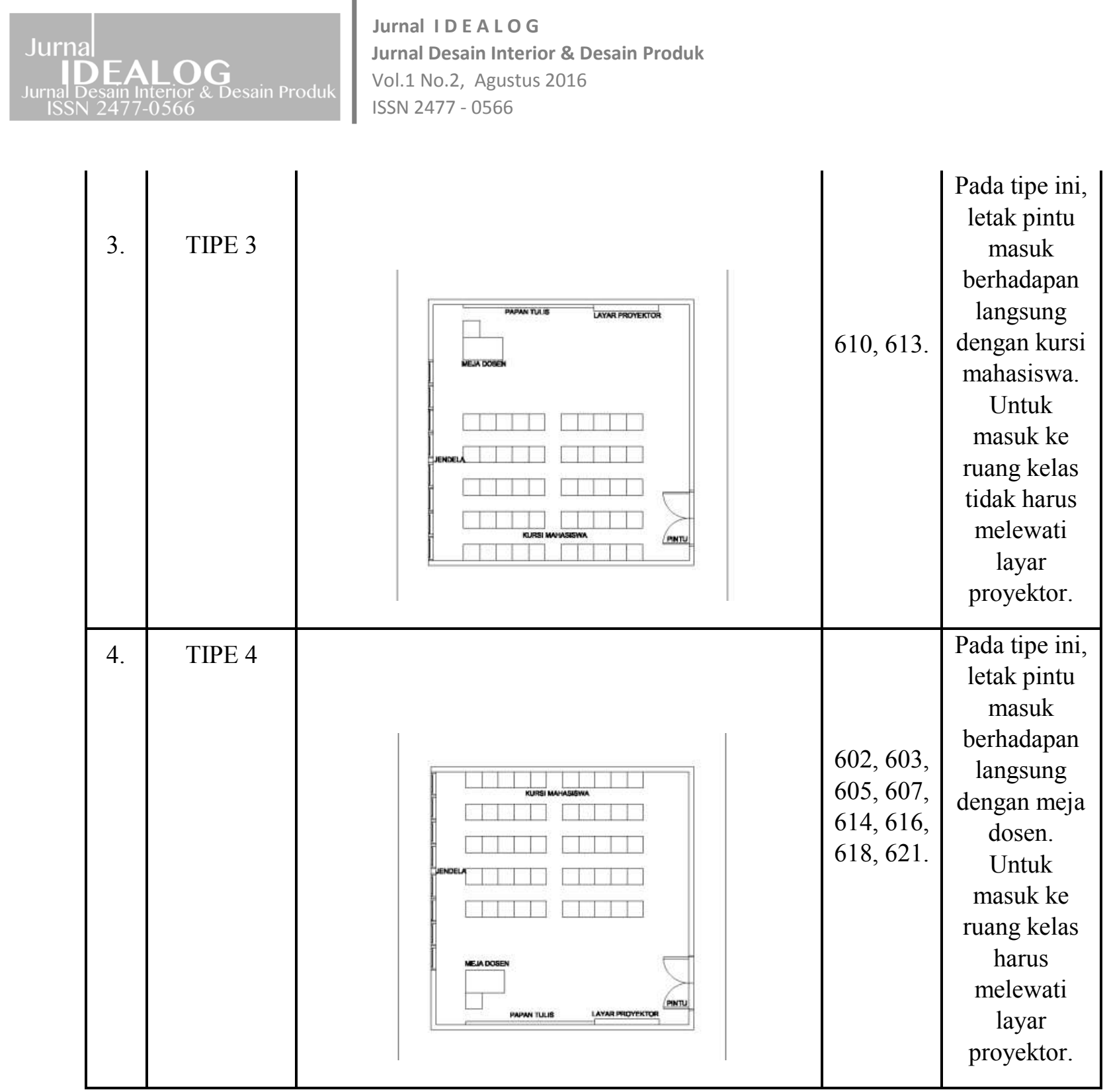

Sumber: pribadi

Terdapat 8 kelas dengan tipe 1, 2 kelas dengan tipe 2, 2 kelas dengan tipe 3, dan 8 kelas dengan tipe 4. Berikut penyusunan tipe konfigurasi pada layout ruang perkuliahan lantai 6 Gedung Tokong Nanas: 

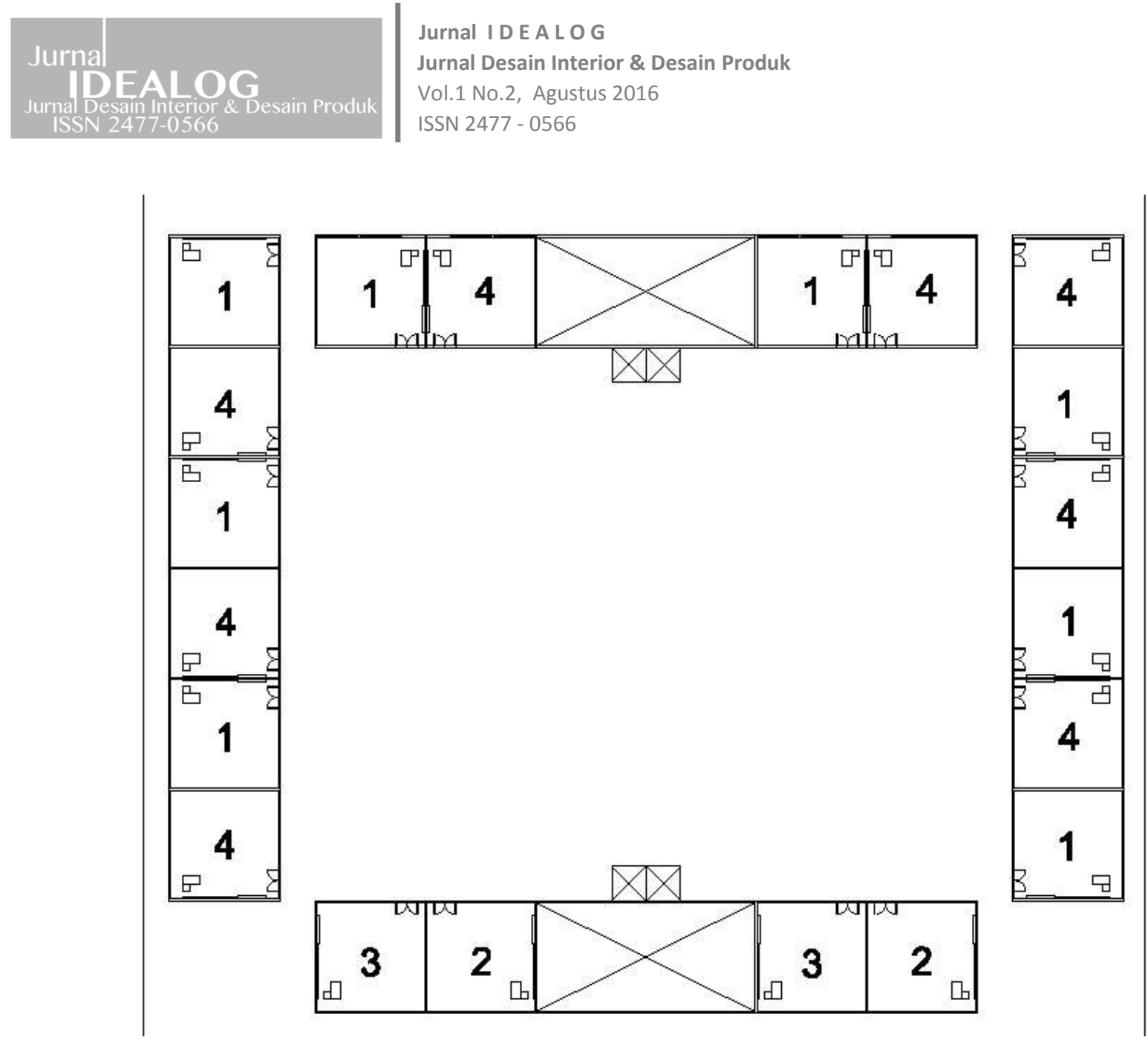

Gambar 3. Penyusunan Tipe Konfigurasi Layout Lantai 6

Sumber: pribadi

\subsection{Aktivitas pada Ruang Perkuliahan}

Terdapat beberapa aktivitas mahasiswa pada saat proses belajar berlangsung. Aktivitas ditinjau dari keterkaitannya dengan posisi duduk. Berikut adalah bagan yang menunjukkan aktivitas yang dilakukan pengguna ruang yang berhubungan dengan desain layout : 

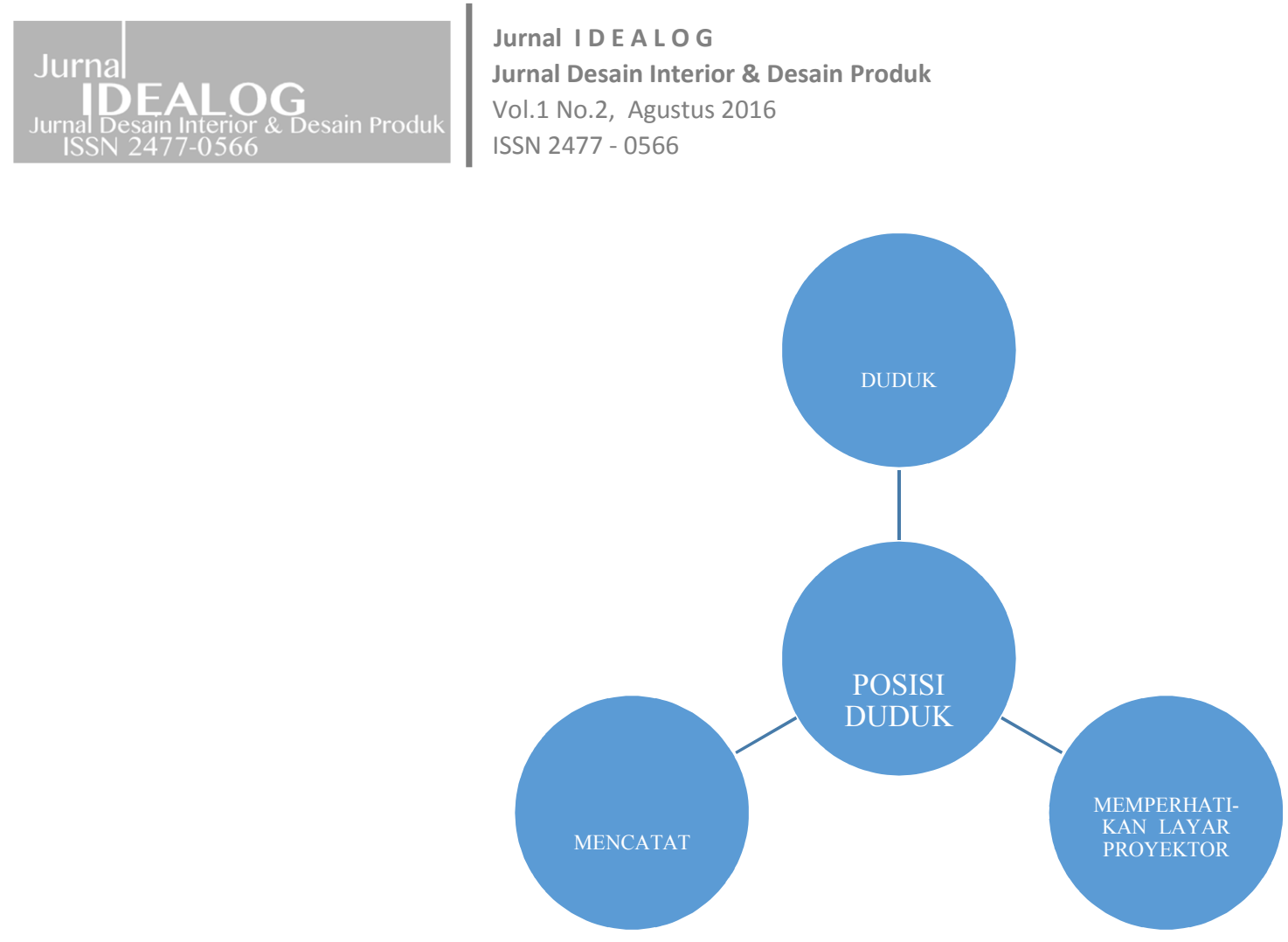

Sumber: pribadi

Bagan 1. Aktivitas Pengguna dan Hubungannya dengan Desain Layout

Aktivitas yang dilakukan mahasiswa saat posisi duduk adalah duduk dan memperhatikan materi yang diberikan oleh dosen pada layar proyektor. Aktivitas lain yaitu mencatat baik tugas kuliah maupun materi yang diberikan dosen.

\subsection{Posisi Duduk yang mempengaruhi Konsentrasi Belajar berdasarkan Aktivitas Pengguna}

Terdapat 2 hal yang dapat mempengaruhi konsentrasi belajar berdasarkan posisi duduk, yaitu sudut pandang penglihatan dan jarak penglihatan. Pada sudut pandang penglihatan dibagi menjadi 2 yaitu sudut pandang penglihatan secara horizontal dan sudut pandang penglihatan secara vertikal. Berikut pembahasan mengenai sudut pandang penglihatan secara horizontal, sudut pandang penglihatan secara vertikal, dan jarak penglihatan :

\section{Sudut Pandang Penglihatan secara Horizontal}


Pengukuran sudut horizontal menggunakan busur dilakukan dengan acuan titik tengah layar terhadap area terluar posisi duduk. Standar yang dipakai untuk ukuran ini adalah $45^{\circ}+45^{\circ}$ (University of Maryland, 2000), (Ahlstrom, 2007). Sehingga standar sudut penglihatan dari kursi terjauh ke layar proyektor maksimal adalah $45^{\circ}$. Ini berlaku untuk sudut sebelah kanan maupun kiri layar proyektor. Berikut adalah gambar pengukuran sudut pandang penglihatan terjauh dan terdekat secara horizontal dari layar proyektor :

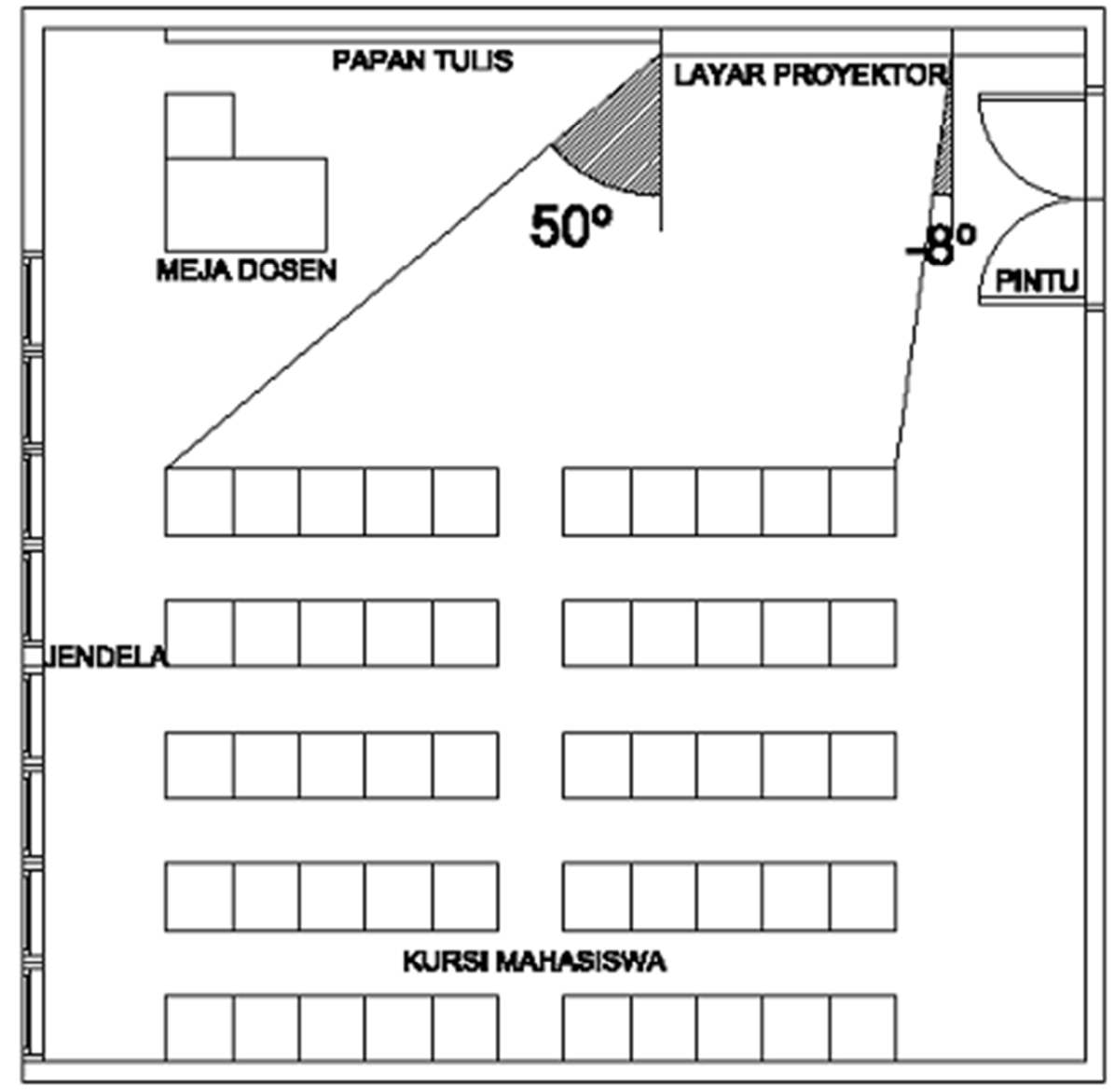

Sumber: pribadi

Gambar 4. Pengukuran Sudut Pandang Penglihatan

Terjauh dan Terdekat dari Layar Proyektor

Ruang perkuliahan memiliki sudut pandang penglihatan terjauh sebesar $50^{\circ}$ di sebelah kiri dan sudut pandang penglihatan terdekat $-8^{\circ}$ di sebelah kanan. Sudut pandang penglihatan terjauh yang tampak pada gambar (di sebelah kiri) melewati $5^{\circ}$ dari batas standar sudut pandang penglihatan secara horizontal. 


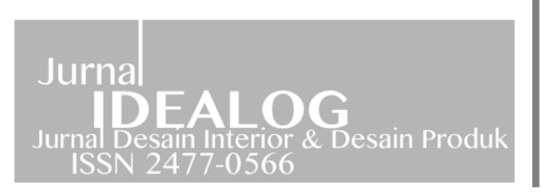

Ini berdampak mahasiswa yang duduk di area kursi terjauh kesulitan melihat tulisan di layar proyektor. Sedangkan sudut kanan $-8^{\circ}$ sudah sesuai dengan standar namun kurang optimal karena area layar proyektor yang terlalu ke kanan melewati barisan paling kanan mahasiswa (tidak tegak lurus).

\section{Sudut Pandang Penglihatan secara Vertikal}

Pengukuran sudut horizontal menggunakan busur dilakukan dengan mengukur jarak kursi terhadap layar proyektor. Standar yang dipakai untuk ukuran ini adalah $30^{\circ}$ (University of Maryland, 2000), (Ahlstrom, 2007). Sehingga standar sudut penglihatan dari kursi terjauh ke layar proyektor maksimal adalah $45^{\circ}$. Ini berlaku untuk sudut pada posisi terdepan maupun terbelakang dari layar proyektor. Berikut adalah gambar pengukuran sudut pandang penglihatan terjauh dan terdekat secara vertikal dari layar proyektor :

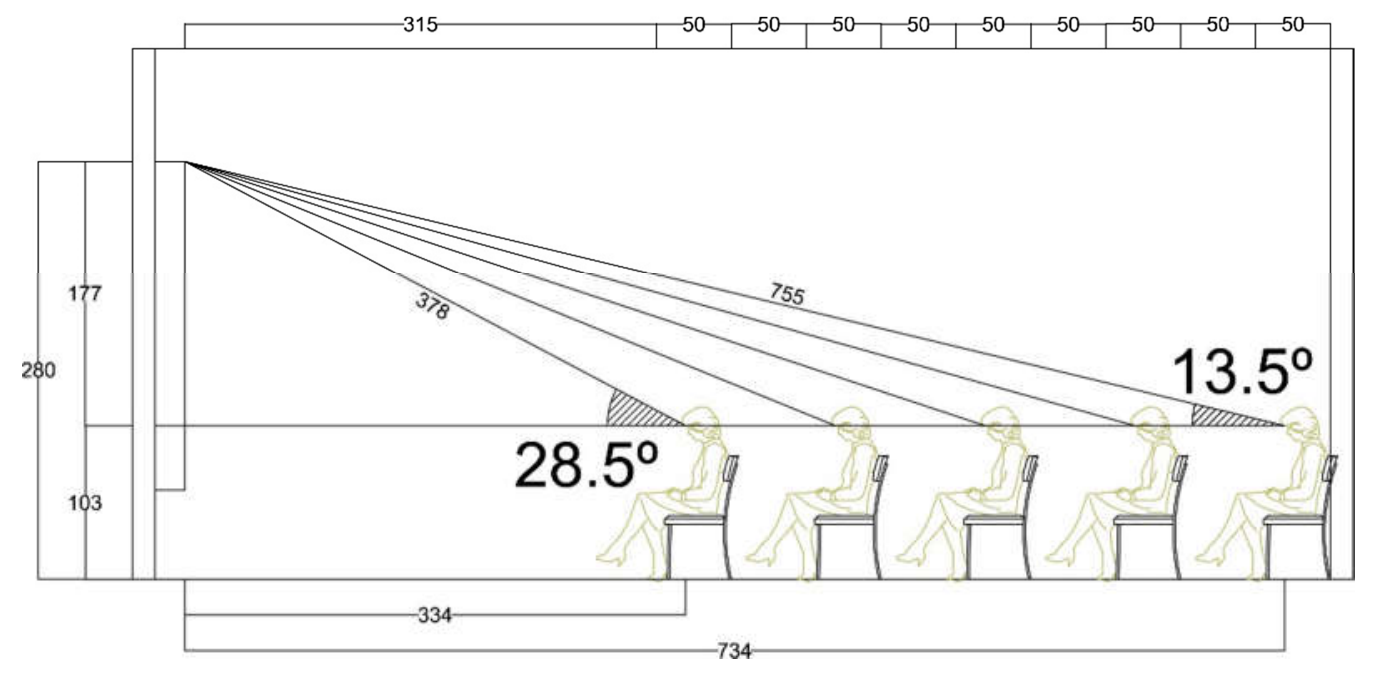

Sumber: pribadi

Gambar 6. Pengukuran Sudut Pandang Penglihatan secara Vertikal

Terdapat 5 deret posisi duduk jika dilihat secara vertikal. Tinggi tegak lurus penglihatan dari lantai adalah $103 \mathrm{~cm}$. Tinggi tegak lurus penglihatan ke layar proyektor adalah $177 \mathrm{~cm}$. Tinggi layar proyektor dari lantai adalah 280 . Berikut adalah sudut antar masing-masing deret tempat duduk ke layar proyektor : 




Tabel 3. Sudut Pandang Penglihatan dari Tempat Duduk ke Layar Proyektor

\begin{tabular}{|c|c|}
\hline DERET & BARIS ( A-J ) \\
\hline 1 & $28.5^{\circ}$ \\
\hline 2 & $24.75^{\circ}$ \\
\hline 3 & $21^{\circ}$ \\
\hline 4 & $17.25^{\circ}$ \\
\hline 5 & $13.5^{\circ}$ \\
\hline
\end{tabular}

Sumber: pribadi

Untuk perhitungan sudut pandang vertikal, standar penglihatan $>30^{\circ}$. Ini digunakan baik duduk pada posisi terjauh hingga posisi terdekat. Ruang perkuliahan memiliki sudut pandang penglihatan terdekat sebesar $28.5^{\circ}$ dan sudut pandang penglihatan terjauh sebesar $13.5^{\circ}$. Dalam ruang perkuliahan ini, sudut pandang penglihatan terdekat dan terjauh secara vertikal telah memenuhi standar sudut pandang penglihatan ke layar proyektor secara vertikal yaitu $>30^{\circ}$.

\section{Jarak Kursi Terdekat dan Terjauh dari Layar Proyektor}

Pengukuran jarak dilakukan dengan mengukur jarak kursi terhadap layar proyektor. Standar untuk jarak kursi terdekat dekat dengan layar adalah 2xH, dimana $\mathrm{H}$ adalah tinggi layar, sedangkan standar kursi terjauh dari layar adalah 6Xh (University of Maryland, 2000), (Ahlstrom, 2007). Berikut adalah gambar pengukuran jarak kursi terjauh dan terdekat secara horizontal dari layar proyektor 




Gambar 5. Pengukuran Jarak Kursi secara Horizontal

Sumber: pribadi

Terdapat 5 posisi duduk secara yang diberi nama 1,2,3,4, dan 5. Terdapat 10 posisi duduk secara vertikal diberi nama A,B,C,D,E,F,G,H,I, dan J. Berikut adalah jarak antar masing-masing tempat duduk ke layar proyektor :

Tabel 2. Jarak Tempat Duduk ke Layar Proyektor (mm)

\begin{tabular}{|c|c|c|c|c|c|c|c|c|c|c|}
\hline & A & B & C & D & E & F & G & H & I & J \\
\hline 1 & 570 & 529 & 490 & 453 & 418 & 360 & 339 & 324 & 316 & 316 \\
\hline 2 & 631 & 594 & 559 & 527 & 498 & 450 & 433 & 422 & 416 & 416 \\
\hline 3 & 701 & 668 & 637 & 609 & 584 & 544 & 530 & 520 & 516 & 516 \\
\hline
\end{tabular}




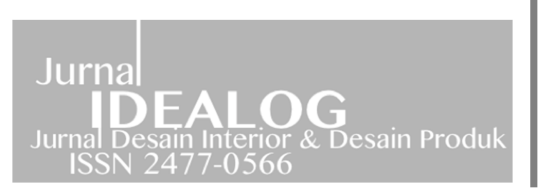

\begin{tabular}{|c|c|c|c|c|c|c|c|c|c|c|}
\hline 4 & 777 & 748 & 720 & 696 & 674 & 639 & 628 & 620 & 615 & 615 \\
\hline 5 & 858 & 832 & 807 & 785 & 755 & 736 & 726 & 719 & 715 & 715 \\
\hline
\end{tabular}

Sumber: pribadi

Terlihat pada tabel terdapat jarak terdekat dan terjauh tempat duduk ke layar proyektor. Jarak tedekat berada diposisi 1I dan 1J yaitu $316 \mathrm{~mm}$. Jarak terjauh berada diposisi 5A yaitu $858 \mathrm{~mm}$.

Sesuai dengan standar untuk jarak penglihatan terdekat dengan layar secara horizontal adalah $2 \mathrm{xH}$ dan jarak penglihatan terjauh dengan layar proyektor secara horizontal adalah $6 \mathrm{xH}$. $\mathrm{H}$ adalah tinggi layar. Berikut jarak terdekat dan terjauh yang sesuai dengan standar (University of Maryland, 2000), (Ahlstrom, 2007) :

\section{H ( tinggi layar) $\quad: 177 \mathrm{~cm}$ \\ Jarak Terdekat $\quad: 2 \times 177 \mathrm{~cm}=354 \mathrm{~cm}$}

Gambar 6. Pengukuran Jarak Terdekat dan Terjauh

Sumber: pribadi

Ruang perkuliahan memiliki jarak penglihatan terjauh sebesar $858 \mathrm{~cm}$ dan jarak penglihatan terdekat sebesar $316 \mathrm{~cm}$. Jarak terdekat dari kursi ke layar proyektor $(316 \mathrm{~cm})$ kurang dari standar yaitu kurang $38 \mathrm{~cm}$ dari standar jarak terdekat posisi kursi dengan layar proyektor. Ini berdampak pada penglihatan mahasiswa yang duduk pada posisi depan karena terlalu dekat dengan layar. Sedangkan jarak terjauh dari kursi ke layar proyektor $(858 \mathrm{~cm})$ sudah memenuhi standar jarak terjauh yaitu tidak lebih dari $1062 \mathrm{~cm}$.

\section{Kesimpulan}

Pada pembahasan disebutkan posisi duduk mempengaruhi efektivitas belajar mahasiswa. Adapun faktor-faktor dari posisi duduk yang mempengaruhi yaitu sudut pandang penglihatan baik secara horizontal maupun vertikal dari tempat duduk ke layar proyektor dan jarak tempat duduk ke layar proyektor. Berikut pengaruh sudut pandang penglihatan baik secara horizontal 
maupun vertikal dari tempat duduk ke layar proyektor dan jarak tempat duduk ke layar proyektor terhadap efektivitas belajar:

Tabel 3. Pengaruh Efektivitas Belajar dari Posisi Duduk

\begin{tabular}{|c|c|}
\hline \multicolumn{2}{|c|}{ SUDUT PANDANG PENGLIHATAN (HORIZONTAL) } \\
\hline+ & - \\
\hline $\begin{array}{c}\text { Standar minimal sudut penglihatan } \\
\text { adalah }-45^{\circ} \text {. }\end{array}$ & $\begin{array}{c}\text { Standar maksimal sudut penglihatan } \\
\text { adalah } 45^{\circ} .\end{array}$ \\
\hline $\begin{array}{l}\text { Sudut minimal sudah memenuhi } \\
\text { standar. }\end{array}$ & Sudut melewati $5^{\circ}$ dari batas standar. \\
\hline Ini dapat menunjang kefokusan belajar. & $\begin{array}{c}\text { Ini berdampak kesulitan melihat tulisan dan } \\
\text { kefokusan terganggu. }\end{array}$ \\
\hline \multicolumn{2}{|c|}{ Sudut penglihatan paling ideal adalah $0^{\circ}$. } \\
\hline \multicolumn{2}{|c|}{ SUDUT PANDANG PENGLIHATAN (VERTIKAL) } \\
\hline+ & - \\
\hline \multicolumn{2}{|l|}{$\begin{array}{c}\text { Untuk perhitungan sudut vertikal, } \\
\text { standar penglihatan }>30^{\circ}\end{array}$} \\
\hline \multicolumn{2}{|l|}{$\begin{array}{l}\text { Ruang kelas memiliki sudut penglihatan } \\
\text { terdekat sebesar } 28.5^{\circ} \text { dan sudut penglihatan } \\
\text { terjauh sebesar } 13.5^{\circ} \text {. Dalam ruang } \\
\text { perkuliahan ini, sudut penglihatan terdekat } \\
\text { dan terjauh secara vertikal telah memenuhi } \\
\text { standar penglihatan dari sudut vertikal. Ini } \\
\text { dapat menunjang kefokusan belajar. }\end{array}$} \\
\hline \multicolumn{2}{|c|}{ JARAK TEMPAT DUDUK } \\
\hline+ & - \\
\hline Jarak Terdekat: $2 \times 177 \mathrm{~cm}=354 \mathrm{~cm}$. & Jarak Terjauh: 6 x177 cm= $1062 \mathrm{~cm}$. \\
\hline Jarak terdekat kurang $38 \mathrm{~cm}$ dari standar. & $\begin{array}{c}\text { Jarak terjauh sudah memenuhi standar yaitu } \\
858 \mathrm{~cm} \text { (tidak lebih dari } 1062 \mathrm{~cm}) .\end{array}$ \\
\hline $\begin{array}{l}\text { Berdampak mahasiswa melihat terlalu dekat } \\
\text { dengan layar. }\end{array}$ & Ini dapat menunjang kefokusan belajar. \\
\hline Jarak tempat duduk ke layar pr & ktor paling ideal adalah $708 \mathrm{~cm}$. \\
\hline
\end{tabular}


Hasil analisa menunjukkan sudut pandang tidak berpengaruh terhadap deret tapi berpengaruh terhadap baris. Semakin jauh tempat duduk maka semakin kecil sudut. Sudut pandang tidak berpengaruh terhadap layar proyektor. Sehingga secara garis besar dapat disimpulkan bahwa posisi duduk (baik horizontal maupun vertikal) berpengaruh pada efektivitas mahasiswa dalam proses belajar.

Pada ruang perkuliahan di Gedung Tokong Nanas ini secara umum sudah memenuhi standar. Namun terdapat beberapa aspek yang belum memenuhi standarnya. Adapun yang belum memenuhi standarnya yaitu pada sudut pandang penglihatan secara horizontal melewati standar maksimal. Ini berdampak mahasiswa kesulitan melihat tulisan dan kefokusan terganggu. Selain itu jarak terdekat tempat duduk terlalu dekat dengan layar proyektor.

Diharapkan penelitian ini dapat dilanjutkan lebih spesifik guna mengetahui bagaimana layout yang menerapkan standar ergonomi dan anthropometri dapat menunjang kefokusan mahasiswa. Sehingga nantinya dapat diterapkan secara langsung dalam ruang perkuliahan Gedung Tokong Nanas maupun ruang perkuliahan lainnya.

\section{Daftar Pustaka}

[1] Ahlstrom, V., \& Kudrick, B., Human Factors Criteria for Display s : A Human Factors Design Standard Update of Chapter 5, Departement of Transportation, Uni Soviet, (2007).

[2] Syah, Muhibbin.Psikologi Belajar, PT. Raja Grapindo Persada, Jakarta, (2006).

[3] Universitas Maryland. Lecture Hall Design Standards University of Maryland, Baltimore, (2000).

[4] De Chiara \& Callender. 1980. Time Saver Standard for building types $2^{\text {nd }}$ edition. Mc Graww Hill Book Company, New York.

[5] Haryadi, B Setiawan. 1995. Arsitektur Lingkungan dan Perilaku. Proyek Pengembangan Pusat Studi Lingkungan. Direktorat Jenderal Pendidikan Tinggi Departemen Pendidikan dan Kebudayaan, Republik Indonesia. 